\title{
Chapter 4 \\ What Motivates Farm-Level Adaptation in India? A Systematic Review
}

\author{
Chandra Sekhar Bahinipati and Unmesh Patnaik
}

\section{Highlights}

- A systematic review of determinants of farm-level adaptation measures in India.

- Lack of research with respect to climatic factors, perception and risk attitude behaviour and government policies.

- Although behavioural economics discourse has a lot to do with human behaviour, there is little research on this in the climate change adaptation research in India.

- We identify the gaps in adaptation research in India, so it provides a scope for scholarly communities to expand the domains of future research.

\subsection{Introduction}

Several studies report the negative impact of climate change on agriculture in India, now and in the foreseeable future (Pingali, 2019). Half of the labour force in India is engaged in agriculture and has been facing climate-related stress. In view of this, agricultural policies in India always aim to enhance uptake of adaptation mechanisms and to reduce variability in farmer's income. Previous studies acknowledge farmlevel adaptation options undertaken by Indian farmers to reduce potential damage to crops from climate change and extreme events (Aryal et al., 2019). This includes

\footnotetext{
C. S. Bahinipati $(\bowtie)$

Department of Humanities and Social Sciences, Indian Institute of Technology Tirupati, Yerpedu, Tirupati 517619, India

e-mail: csbahinipati@iittp.ac.in

U. Patnaik

Centre for Climate Change \& Sustainability Studies, School of Habitat Studies, Tata Institute of Social Sciences, Mumbai 400088, India

e-mail: unmesh.patnaik@tiss.edu
} 
crop diversification, drought/flood tolerant seeds, altering crop-calendar, crop choice; water management options, soil conservation techniques, etc. (see Below et al., 2010). Although there is a paucity of micro-level studies to estimate pecuniary benefits in India, Patnaik, Das and Bahinipati (2019) find that adopters are getting more output and revenue in the drought-prone regions. Further, Cariappa et al. (2020) observe that insured agricultural households have more crop income and less outstanding debt. There are numerous qualitative papers that point out the positive benefits of adaptation (Singh, 2020). Several papers from South Asia also document farmer adaptation in context of flood in India and Pakistan (Ahmed, 2022, Chap. 7 of this volume and Devi, Sam and Sathyan, 2022, Chap. 8 of this volume), in Sri Lanka drought (Vidanage, Kotagama and Dunusinghe, 2022, Chap. 15 of this volume) and extreme events in India (Ghosh \& Roy, 2022, Chap. 26 of this volume).

Even though several policy initiatives are in place to promote farm-level adaptation measures, a low adoption rate is prevalent across states (see Kharumnuid et al., 2018). Hence, identifying factors that influence farmer's adaptive behaviour is the major research inquiry for several papers. However, there is limited research on a systematic review of the literature on determinants of farm-level adaptation in India, and this chapter attempts to address this gap. The papers by Shaffril, Krauss and Samsuddin (2018) and Dang et al. (2019) are noteworthy exceptions and this chapter builds on Dang et al. (2019) by focussing specifically on Indian literature. This chapter is organised as follows: the next section explains the methodology for selection of papers. The third and fourth sections reflect the factors that influence farmer's adaptive behaviour based on quantitative and qualitative studies. The fifth section provides concluding remarks and highlights the avenues for various research domains in the climate change adaptation research in India.

\subsection{Methods and Materials}

This chapter aims to do a systematic review of determinants of farm-level adaptation options in India. In doing so, it has followed the four strategies of Preferred Reporting Items for Systematic Reviews and Meta-analysis method (PRISMA) method to select articles, i.e. identification, screening, eligibility and the inclusion (Shaffril et al., 2018). With regard to the identification or literature search, several strings/keywords related to farm-level adaptation were used to search articles in the Web of Science database (see Table 4.1). The search was conducted during January 2019, and

Table 4.1 The search string employed to identify studies for systematic review

\begin{tabular}{l|l}
\hline Database & Keywords used \\
\hline Web of science & $\begin{array}{l}\text { ("Climate smart agricultural practices" or "Coping strategies" or "Climate } \\
\text { change adaptation" or "Farm-level adaptation measures") AND ("Farming } \\
\text { Communities" or "Agriculture" or "Farmer") AND ("India") }\end{array}$ \\
\hline
\end{tabular}

Source Author's table 


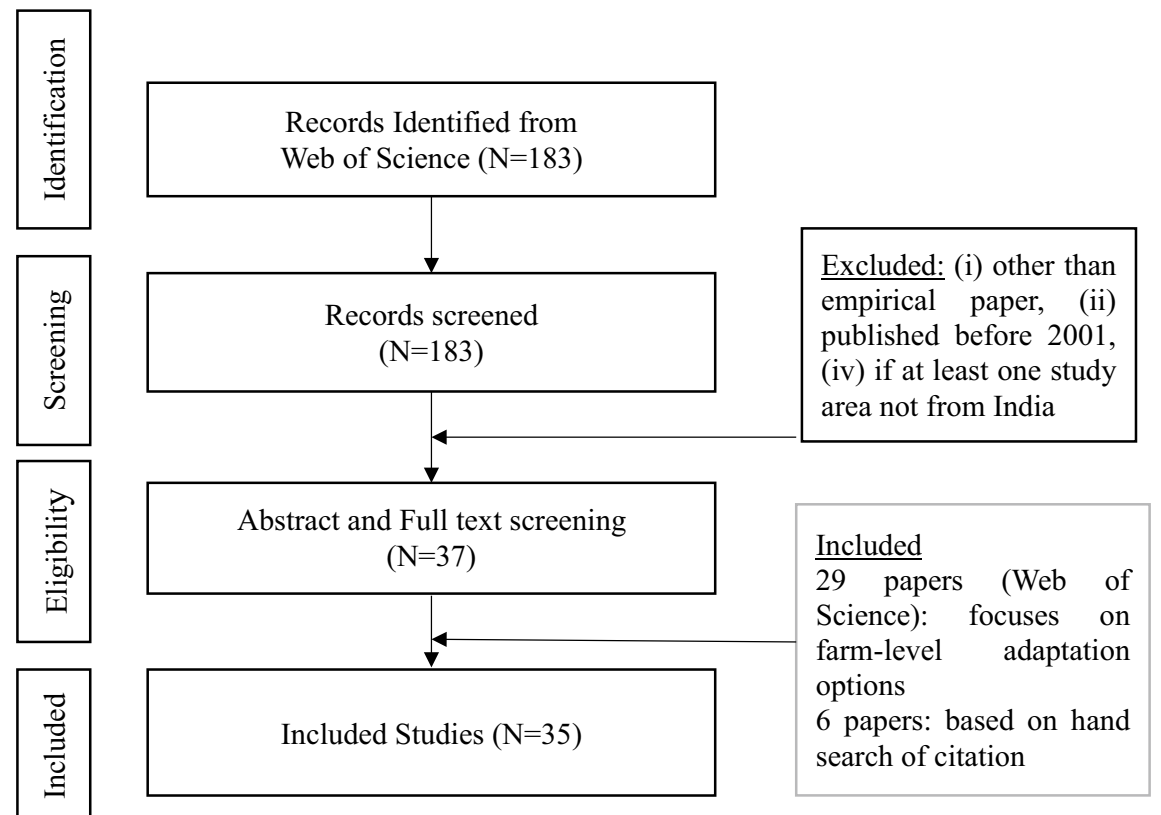

Fig. 4.1 PRISMA flow chart for the selection process. Source Author's figure

therefore, the papers obtained through this search must have been published before December 2018. In doing so, we have identified a total of 183 papers. After this inclusion and exclusion criteria were adopted. Inclusion was based on the literature type (empirical journal paper), time period (between 2001 and 2018), ${ }^{1}$ and country (India). Following this, around 37 articles were selected for the eligibility stage (see Fig. 4.1), and the final selection of 29 papers was based on whether it looks into determinants of farm-level adaptation (See Fig. 4.1). Following Bird et al. (2019), we have also hand-searched citations of articles, and in doing so, we have selected an additional six papers. In sum, we arrived at a basket of 35 papers for systematic review, of which, 12 are quantitative and 23 are qualitative papers (see Fig. 4.2).

\footnotetext{
${ }^{1}$ For the first time, the notion adaptation was discussed in the COP 13 (conference of the parties) held in Bali 2007, and after this, the scholarly communities have given emphasis to different dimensions of adaptation research (Pielke et al., 2007); this is the main reason for choosing the time period between 2001 and 2018.
} 
Fig. 4.2 Description of study design and regional focus. Source Author's figure

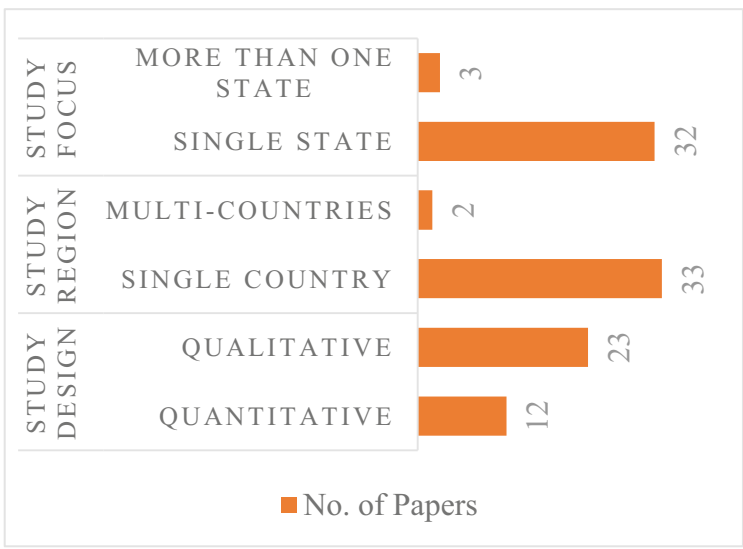

\subsection{Factors Influencing Farmer's Adaptive Behaviour: Quantitative Papers}

The review of quantitative papers reveals that the most frequently used determinants can be classified under seven broad categories, viz. (i) experience/perception on climate variability and extreme events, (ii) other risk and shocks (iii) socio-economic characteristics, (iv) farm characteristics, (v) access to institutions that include formal, informal, development policies and information, (vi) risk attitude behaviour and behavioural anomalies and (vii) others. Seven studies especially focussed on extreme events like cyclonic storms, floods and droughts are Bahinipati and Venkatachalam (2015), Bahinipati (2015), Mehar, Mittal and Prasad, (2016), Panda, (2013), Panda (2013), Patnaik et al. (2019) and Sahu and Mishra (2013). The remaining five papers concentrate on climate variability, monsoon onset, etc., e.g. Jain et al. (2015), Kakumanu et al. (2016), Khatri-chhetri et al. (2017), Kumar et al. (2011) and Patil et al. (2018). Table 4.2 lists out the independent variables taken by the studies in the regression models.

\subsubsection{Climate Change and Extreme Events}

Variables related to climatic aberrations are used as prime explanatory variables to identify whether farmers are adapting to climate change and climate sensitive options. Within these, two variants are found: (i) experienced climate variability and extreme events and (ii) perception. Out of the 12 papers, six focussed on the former while three papers consider variables related to the latter (see Fig. 4.3). Although it is anticipated all the papers should consider variables related to either climate variability and extreme events or perception to find out event specific farm-level adaptation mechanisms, only eight papers have done so. Adaptation takes place in 
4 What Motivates Farm-Level Adaptation in India? A Systematic Review

53

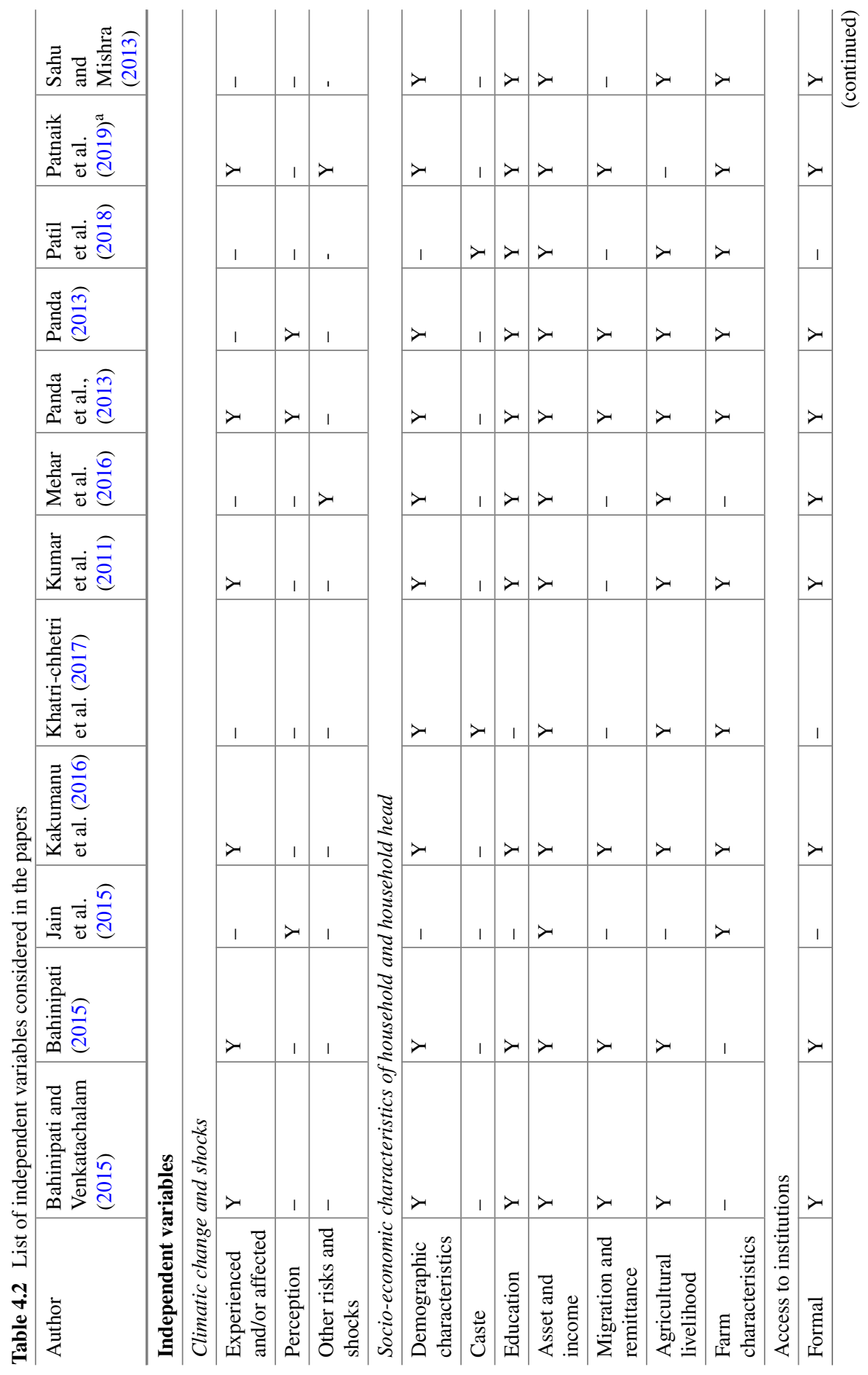




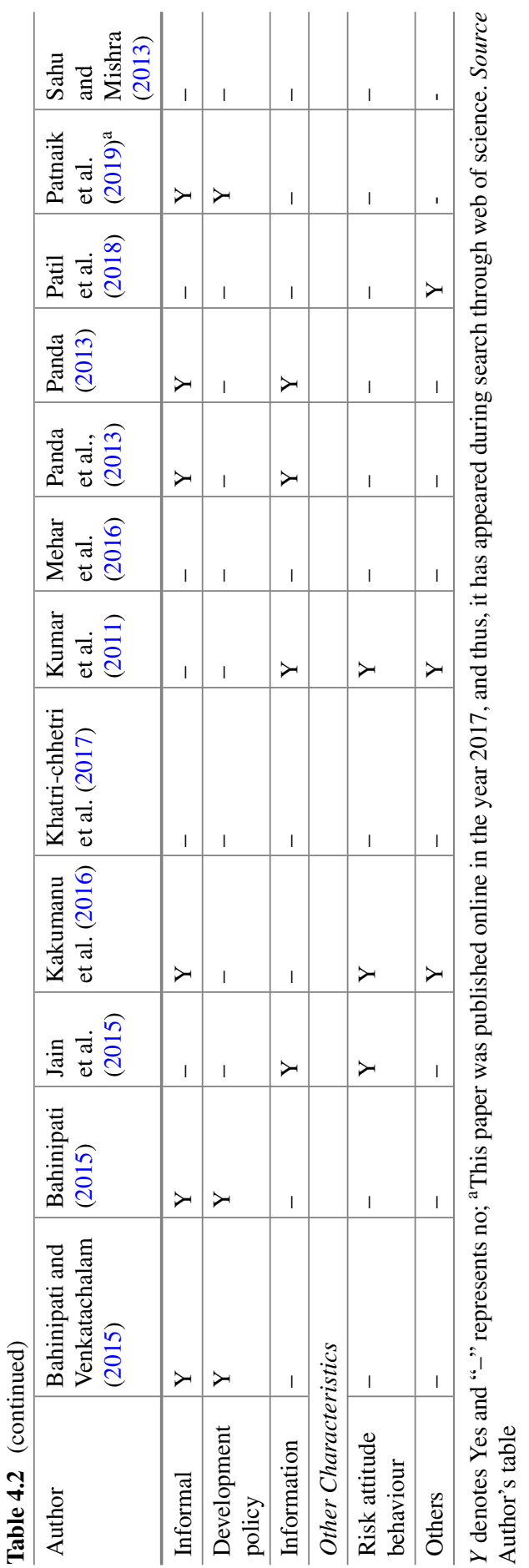


Fig. 4.3 Frequency of determinants appeared in the quantitative papers. Source Author's figure

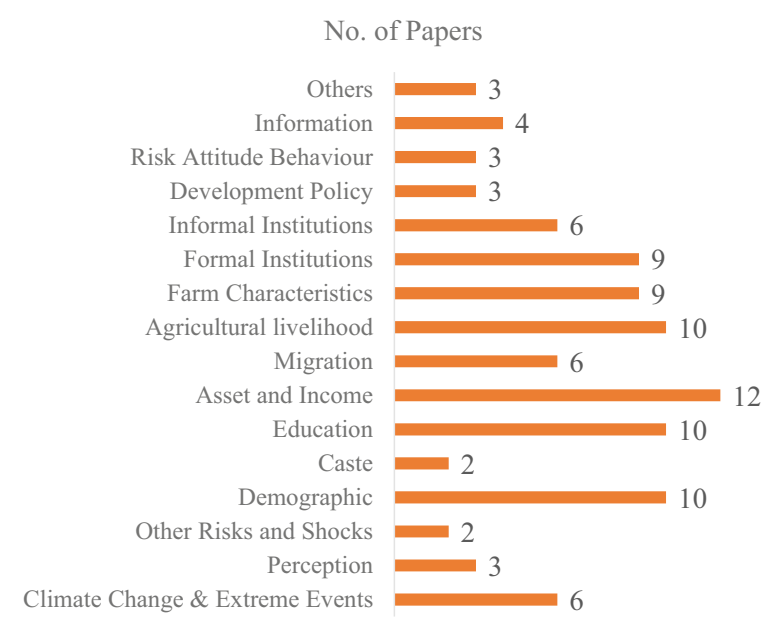

two steps, i.e. first is the farmer's perception about climate change, and then adoption of several adaptation measures (Bahinipati \& Venkatachalam, 2015). Six papers consider extreme events as explanatory variables, and these are Panda (2013), Panda et al. (2013), Bahinipati (2015), Bahinipati and Venkatachalam (2015) and Kakumanu et al. (2016), Patnaik et al. (2019). Bahinipati and Venkatachalam (2015) and Bahinipati (2015) consider three variables to account for the impact of cyclones and floods, e.g. high, moderate and low. Kakumanu et al. (2016) report that variables related to climatic shocks such as drought, untimely rain and irregular weather influence the adoption of farm mechanisation and supplementary irrigation. Likewise, Panda et al. (2013) and Panda (2013) find that loss incurred due to drought has significant positive association with adaptation options, but not statistically significant. Whereas, Patnaik et al. (2019) observe that drought-affected farmers are more likely to undertake agricultural adaptation options.

Further, three papers considered perception as an independent variable, e.g. Jain et al. (2015), Panda et al., (2013) and Panda (2013). Two perception variables were considered by Jain et al. (2015), e.g. total rainfall amount and timing of monsoon onset $^{2}$, and in fact, these confounders are reported as the strongest determinant for farmer's adoption behaviour. As per Panda et al., (2013) and Panda (2013), perceived drought has significant relationship with water conservation, and likewise, perceived change in time of first rain affects farmers' decision on planting timing.

\footnotetext{
${ }^{2}$ In particular, farmers were asked to report whether they have observed any change in the total amount of rainfall and the monsoon onset date (Jain et al., 2015).
} 


\subsubsection{Other Covariate and Idiosyncratic Risks}

Apart from climatic aberrations, other covariate and idiosyncratic risks also negatively affect farmer's well-being, and as a result, it could have a spillover effect on farmer's adaptation decisions. Two papers have taken variables to capture the impact of other risks (see Fig. 4.3). Three variables, for instance, were considered by Patnaik et al. (2019) and those are infant mortality rate, health expenditure and number of months of food scarcity. Similarly, one variable such as food security status was taken by Mehar et al. (2016). The infant mortality rate positively influences farmer's behaviour (Patnaik et al., 2019). With reference to food security, Mehar et al. (2016) observe that farmers facing food shortages are more likely to adapt, whereas Patnaik et al. (2019) find a negative association.

\subsubsection{Socio-economic Characteristics of Household and Household Head}

Numerous studies assert that the combination of social, economic and political factors reflects the adaptive capacity of an entity (Wisner, 2003), and these factors could have influenced farmer's behaviour. We have considered six sub-categories such as demographic characteristics, social category, education, asset and income, migration and remittances and agricultural livelihood. It is observed that most of the papers consider at least one variable from the demographic characteristics (see Fig. 4.3). The indicators mostly used are household size, gender and age of the household head. Except Kakumanu et al. (2016), the remaining papers have taken at most three variables under demographic characteristics. Mixed results are observed across these set of studies. It is expected that literate households are able to access information on various adaptation options, and thus, they are more likely to adapt (Bahinipati \& Venkatachalam, 2015). Hence, a few studies suggested organising farmer-to-farmer meetings for spillover of information (Bahinipati \& Venkatachalam, 2015). Around 10 papers have identified education as one of the determinants, and it is mostly observed as significant across the studies.

The social category of the household as an explanatory variable appeared in two papers; i.e. Khatri-chhetri et al. (2017) and Patil et al. (2018). The latter outlines significant result for the caste variable (Patil et al., 2018). Richer households opt for several adaptation mechanisms because of access to resources, asset and income (Wisner et al., 2003). Besides, Kakumanu et al. (2016), the rest of the papers have taken at most four variables, and the frequently used ones are income, agricultural income, non-agricultural income and asset. Several papers have taken income as one of the variables (Bahinipati, 2015; Bahinipati \& Venkatachalam, 2015), whereas Patnaik et al. (2019) have included asset variable, and Jain et al. (2015) have constructed an asset index. 
Income diversification is considered as a major coping option to smoothen both income and consumption. It is largely adopted by households to withstand all types of risks and shocks, as reported in several papers within the development economics discourse (see Morduch, 1995). In particular, either the household head or other family members migrate for better income opportunities and the remittances enhance adaptive capacity. As a result, the families with at least one migrated member are better equipped to undertake several adaptation measures. It appeared as an explanatory variable in six papers (see Fig. 4.3). If the major share of income comes from agriculture, then those households are more likely to adopt various farm-level adaptation options to reduce potential damage to agricultural crops, and in turn, reduce variability in agricultural income. Around 10 papers have considered agriculture dependency livelihood as one of the variables.

\subsubsection{Farm Characteristics}

Farm characteristics are mostly viewed as a major determinant for taking up adaptation options, because, farmers could undertake measures on the basis of location of land, rainfed/ irrigation, soil quality, etc. Across the studies, the frequently adopted variables are soil characteristics, location of land, irrigation, input use, etc. Around 9 papers have taken up it as one of the independent variables (see Fig. 4.3).

\subsubsection{Access to Institutions}

Adoption of farm-level mechanisms requires capital and liquidity, for which, farmers depend on various formal and informal sources. Around 9 papers consider the former and 7 papers included variables related to the latter (see Fig. 4.3). The papers by Kumar et al. (2011), Bahinipati and Venkatachalam (2015) and Bahinipati (2015) have considered access to formal credit, and crop loss compensation. Panda (2013) and Panda et al. (2013) included access to credit and crop insurance in the model. The access to agricultural extension is taken by Mehar et al. (2016). In regard to informal sources, most of the studies considered borrowing from money lender and self-help groups (Bahinipati, 2015; Bahinipati \& Venkatachalam, 2015; Panda, 2013; Panda et al., 2013; Patnaik et al., 2019). In summary, these variables show a positive association with farmer's adaptation decision.

Around three papers have engaged with development policy-related variables. Termed as generic adaptation measures, they are expected to enhance adaptive capacity of vulnerable households (Sharma \& Patwardhan, 2008). Access to Mahatma Gandhi National Rural Employment Guarantee Scheme (MGNREGS) is used as a confounder by three studies; Bahinipati and Venkatachalam (2015), Bahinipati (2015) and Patnaik et al. (2019). Four papers considered information (agronomic 
and agro-climatic) as variable such as Jain et al. (2015), Kumar et al. (2011) Panda et al. (2013) and Panda (2013).

\subsubsection{Risk Attitude Behaviour and Other Variables}

Farmer's risk preference played a major role in influencing their decision on adoption of agricultural technologies and farm-level measures (Kakumanu et al., 2016). Two papers considered risk attitude behaviour such as Jain et al. (2015) and Kakumanu et al. (2016). Following the Arrow-Pratt absolute risk aversion method, Kakumanu et al. (2016) calculate risk premium and how it is influencing adoption of technology in agriculture. However, none of these studies have examined behavioural anomalies. In fact, behavioural economics discourse in recent past years has significantly contributed to how different behavioural anomalies influence people's choice architecture, and the possible anomalies are status quo bias, uncertainty and discounting future, social norms, nudge-like interventions, heuristics, etc. Besides these variables, a few other variables are also considered in the econometric models by three papers such as Kakumanu et al. (2016), Kumar et al. (2011) and Patil et al. (2018).

\subsection{Factors Influencing Farmer's Adaptive Behaviour: Qualitative Papers}

A contribution of the present chapter is the inclusion of findings from qualitative papers in the review. In total, we include around 23 papers for this review with the study areas spread over entire India. Appendix outlines different determinants of farm-level adaptation options extracted from these papers. The stressor across all these papers is climate variability and climate-related extreme events from droughts to cyclonic storms and floods. Around 11 papers focus on climate variability, and 3 papers consider both climate variability and extreme events. Drought is a major stressor for 8 papers, while one paper is related to cyclonic storm and flood, e.g. Duncan et al. (2017).

Across studies related to climate variability, the reported major constraints are lack of knowledge about adaptation options (e.g. new varieties of seeds, soil conservation techniques, water management options, etc.), credit, wealth, climate information, shortage of inputs, access to agricultural extension, access to market, etc. (Kharumnuid et al., 2018; Singh et al., 2018b; Singh, 2017, 2018a; Tripathi \& Mishra, 2017a, 2017b). Kharumnuid et al. (2018) and Tripathi and Mishra (2017a, 2017b) outline that although the farmers perceive a change in climate over a temporal scale, they are not adopting effective mechanisms. Singh, (2018a) finds that farmers mostly rely on short-term coping options. Rao (2017) suggest creation of farm-ponds in the semi-arid regions of Telangana to arrest rapid decline of groundwater level. Only 
one paper discusses the gender dimension of adaptation (Singh, 2017). Around three papers focus on climate information. These papers indicate that climate information influences farmer's adaptation decision in Maharashtra (Lobo, Chattopadhyay and Rao, 2017), West Bengal (Mishra, 2013) and Tamil Nadu (Rengalakshmi, Manjula and Devaraj, 2018), and dissemination of information through mobile phone was found to be most cost-effective (Lobo et al., 2017). In Maharashtra and Tamil Nadu, social network, farmer-to-farmer interaction, agricultural extension service, training, technology know how and interaction between farmer, financial institutions and local government should be initiated for large scale dissemination of climate information (Lobo et al., 2017; Rengalakshmi et al., 2018). Looking at both climate variability and extremes, Bhatta et al. (2016a, 2016b) conclude that adaptation options are driven by rainfall patterns, and more emphasis should be given for social protection, participatory action research to identify climate smart agricultural options, and widen the focus area of agricultural research, policy and development agencies. Also, marketrelated drivers are observed as major determinants for changing agricultural practices (Bhatta et al., 2016a).

Studies related to drought have taken case studies from Andhra Pradesh (Balaji, Ganapuram, and Devakumar2015; Banerjee, 2015; Banerjee et al., 2013), South India (Venot, ), Odisha (Mishra \& Mishra, 2010; Panda, 2016), Gujarat (Mwinjaka, Gupta, and Bresser, 2010) and Maharashtra (Banerjee, 2015; Banerjee et al., 2013; Udmale, 2014). Balaji et al. (2015) infer that the likelihood of adoption of options is high for smallholder farmers if they are part of the learning process. Banerjee et al. (2013) observe the major constraints are poor governance, lack of collective action, inequality, political influence and social exclusion. Venot et al. (2010) observe that farmers in South India are opting for short-term coping measures. The intensity of droughts is seen as key for adoption of adaptation mechanisms in Odisha (Mishra \& Mishra, 2010). Panda (2016) mentions that at the community level, the constraints are lack of government intervention, no knowledge about drought resistant crops, lack of renovation of water bodies and irrigation systems. Overall, integration of indigenous knowledge and traditional practices with scientific knowledge and development planning is supported by Banerjee et al. (2015) and Singh et al. (2018a), Singh et al. (2018b).

\subsection{Concluding Remarks}

Adopting farm-level options is imperative for the farmers in India to mitigate potential damages to agricultural output. Over the years, low uptake was cited across the studies, and therefore, identifying determinants is a major research question for several papers. There is a gap in the literature with regard to comprehensive reviews of existing studies examining the factors that facilitate farmers to adopt farm-level adaptation measures. This chapter attempts to address this by reviewing 12 quantitative and 23 qualitative papers published between 2001 and 2018. We have come up 
with four major conclusions. First, non-climatic factors like demographic characteristics, asset and income, education, dependency on agriculture, farm characteristics and access to financial institutions are observed as major motivating factors. Second, this chapter advocates future studies to establish the causal relationship of farmlevel adaptation options with climate change and extreme events and to identify climate and extreme event specific adaptation measures. Third, there is a paucity of studies with reference to perception, risk attitude behaviour, climate information and development-related policies. Fourth, although behavioural economics discourse has lot to do with human behaviour, little research has been taken up on climate change adaptation research in India. These findings provide important avenues for scholarly communities and policy makers for expanding the domains of future research while realigning existing plans to address the observed gaps and develop evidence-based policies to undertake adaptation mechanisms.

Although research on issues related to agriculture is extensive in India, focus on the aspects related to the impact of climatic aberrations and extremes started only during the past one and half decades. We have attempted to include papers in this chapter based on seemingly robust inclusion criteria, but the non-inclusion of many research articles related to agricultural interventions has been a limitation. Further, we have excluded several papers in grey literature. Another limitation of the review is that we have not examined the farm-level adaptation decisions across different categories of farmers, for instance, large farmers compared to small and marginal ones. A final weakness concerns the exclusion of non-farm adaptation measures. Addressing some of these could be a starting point for future research.

Acknowledgements The first author has received financial support from the Indian Institute of Technology Tirupati, Yerpedu, India through the New Faculty Initiative Grant (NFIG) to carry out this study. The authors would like to acknowledge the research support received from Vijay Kumar and Dinamani Biswal. The usual disclaimers apply.

\section{Appendix: Summary of Major Findings from the Qualitative Studies}

\begin{tabular}{l|l|l|l}
\hline S. No. & Author (Yyear) & Study location & Major findings \\
\hline & Climate variability & \multicolumn{2}{l}{} \\
\hline
\end{tabular}


(continued)

\begin{tabular}{|c|c|c|c|}
\hline S. No. & Author (Yyear) & Study location & Major findings \\
\hline 1 & Kharumnuid et al. (2018) & Meghalaya & $\begin{array}{l}\text { - Large percentage of } \\
\text { households undertake } \\
\text { medium level adaptation, } \\
\text { i.e. persistence of } \\
\text { adaptation deficit } \\
\text { - Major constraints: market } \\
\text { price distortion, lack of } \\
\text { technical knowhow, } \\
\text { communication and market, } \\
\text { shortage of inputs, } \\
\text { particularly quality seeds } \\
\text { and non-availability of } \\
\text { climate information }\end{array}$ \\
\hline 2 & Lobo et al. (2017) & Maharashtra & $\begin{array}{l}\text { - Dissemination of } \\
\text { agro-climatic information } \\
\text { through mobile is } \\
\text { cost-effective } \\
\text { - Training and awareness } \\
\text { campaign, technology } \\
\text { knowhow and interaction } \\
\text { among the farmers, civil } \\
\text { society organisations, } \\
\text { financial institutions and } \\
\text { local government bodies are } \\
\text { required for further scaling } \\
\text { up }\end{array}$ \\
\hline 3 & Mishra et al. (2013) & West Bengal & $\begin{array}{l}\text { - Access to rainfall forecast } \\
\text { information reduces the use } \\
\text { of water for irrigation }\end{array}$ \\
\hline 4 & Rao et al. (2017) & Telangana & $\begin{array}{l}\text { - Farm pond could reduce } \\
\text { water footprint, in turn, } \\
\text { increase groundwater level, } \\
\text { and hence, increase cropped } \\
\text { area and productivity }\end{array}$ \\
\hline 5 & Rengalakshmi et al. (2018) & Tamil Nadu & $\begin{array}{l}\text { - Climate information should } \\
\text { be context specific and gender } \\
\text { sensitive, and integration of } \\
\text { traditional knowledge with } \\
\text { scientific information is } \\
\text { essential } \\
\text { - Social network, } \\
\text { farmer-to-farmer } \\
\text { interaction and agricultural } \\
\text { extension services should } \\
\text { be promoted for large scale } \\
\text { dissemination of climate } \\
\text { information }\end{array}$ \\
\hline
\end{tabular}


(continued)

\begin{tabular}{|c|c|c|c|}
\hline S. No. & Author (Yyear) & Study location & Major findings \\
\hline 6 & Singh et al. (2016) & Rajasthan & $\begin{array}{l}\text { - Apart from resource } \\
\text { endowment, social } \\
\text { cognitive factors like } \\
\text { perceived adaptive capacity } \\
\text { and efficacy to carry out } \\
\text { adaptation options } \\
\text { influence farmers' decision }\end{array}$ \\
\hline 7 & Singh et al. (2017) & Arunachal Pradesh & $\begin{array}{l}\text { - Gender and wealth are } \\
\text { found as major } \\
\text { determinants }\end{array}$ \\
\hline 8 & Singh et al., (2018a) & Karnataka & $\begin{array}{l}\text { - Responses are } \\
\text { multi-dimensional; vary } \\
\text { with geography, identity, } \\
\text { social capital and economic } \\
\text { status } \\
\text { - Farmers rely more on } \\
\text { short-term coping strategies } \\
\text { and less long-term } \\
\text { measures } \\
\text { - Interventions may not be } \\
\text { climate specific, therefore, } \\
\text { integration of climate } \\
\text { component is necessary, i.e. } \\
\text { comprehensive } \\
\text { risk-response framework }\end{array}$ \\
\hline 9 & Singh et al. (2018b) & Punjab and Telangana & $\begin{array}{l}\text { - Major constraints are lack } \\
\text { of knowledge, credit, } \\
\text { climate information, land } \\
\text { holding and shortage of } \\
\text { input and agricultural } \\
\text { labour } \\
\text { - Integration of local level } \\
\text { perception and adaptation } \\
\text { strategies in development } \\
\text { planning }\end{array}$ \\
\hline 10 & $\begin{array}{l}\text { Tripathi and Mishra (2017a, } \\
\text { 2017b) }\end{array}$ & Uttar Pradesh & $\begin{array}{l}\text { Farmers perceive climate } \\
\text { variability, but not } \\
\text { undertaking effective } \\
\text { response } \\
\text { - Advises to provide climate } \\
\text { information, extension } \\
\text { services and to organise } \\
\text { capacity building } \\
\text { programme }\end{array}$ \\
\hline & \multicolumn{3}{|c|}{ Climate variability and Extreme Events } \\
\hline
\end{tabular}


(continued)

\begin{tabular}{|c|c|c|c|}
\hline S. No. & Author (Yyear) & Study location & Major findings \\
\hline 11 & Bhatta et al. (2016a) & Bihar & $\begin{array}{l}\text { - Adaptation practices are } \\
\text { associated with rainfall } \\
\text { patterns, e.g. farmers in } \\
\text { medium rainfall areas } \\
\text { (900-1500 mm) are taking } \\
\text { several adaptation practices } \\
\text { - Large farmers undertake } \\
\text { on-farm livelihood options, } \\
\text { and also more innovative } \\
\text { - More emphasis for social } \\
\text { protection, participatory } \\
\text { action research to identify } \\
\text { efficient climate smart } \\
\text { agricultural options; widen } \\
\text { the focus area of } \\
\text { agricultural research, policy } \\
\text { and development agencies }\end{array}$ \\
\hline 12 & Bhatta et al. (2016b) & Bihar & $\begin{array}{l}\text { - Farmers in the high rainfall } \\
\text { region (1500-2100 mm) are } \\
\text { likely to undertake several } \\
\text { on-farm livelihood } \\
\text { diversification activities } \\
\text { - Market-related drivers are } \\
\text { major determinants } \\
\text { - Evokes for developing } \\
\text { rainfall and farmers' } \\
\text { resource endowment } \\
\text { strategies }\end{array}$ \\
\hline \multirow[t]{2}{*}{13} & Pandey (2018) & Uttarakhand & $\begin{array}{l}\text { - Communities are largely } \\
\text { depending on traditional } \\
\text { knowledge and historical } \\
\text { climate information, and } \\
\text { thus, integration of these } \\
\text { with scientific knowledge } \\
\text { could lead to cost-effective } \\
\text { options } \\
\text { - Major barriers are shortage } \\
\text { of cash, lack of information } \\
\text { and awareness }\end{array}$ \\
\hline & \multicolumn{3}{|l|}{ Drought } \\
\hline 14 & Balaji et al. (2015) & Andhra Pradesh & $\begin{array}{l}\text { - High likelihood of } \\
\text { undertaking adaptation by } \\
\text { smallholder farmers when } \\
\text { they are part of a learning } \\
\text { context, e.g. Mobi-MOOC } \\
\text { - Advocates for requirement } \\
\text { of effective channels of } \\
\text { information sharing and } \\
\text { capacity development }\end{array}$ \\
\hline
\end{tabular}


(continued)

\begin{tabular}{|c|c|c|c|}
\hline S. No. & Author (Yyear) & Study location & Major findings \\
\hline 15 & Banerjee et al. (2013) & $\begin{array}{l}\text { Andhra Pradesh and } \\
\text { Maharashtra }\end{array}$ & $\begin{array}{l}\text { - Minimum of impact of } \\
\text { information dissemination } \\
\text { on the poor farmers } \\
\text { - Poor governance, collective } \\
\text { action, inequality, local level } \\
\text { political power and social } \\
\text { exclusion are the major } \\
\text { constraints } \\
\text { - Advocates for undertaking } \\
\text { adaptation at institutional } \\
\text { and community level, so it } \\
\text { minimises the additional } \\
\text { burden on the marginalised } \\
\text { communities. Further, } \\
\text { support to be provided with } \\
\text { respect to finance, } \\
\text { information, technology } \\
\text { and infrastructure }\end{array}$ \\
\hline 16 & Banerjee (2015) & $\begin{array}{l}\text { Andhra Pradesh and } \\
\text { Maharashtra }\end{array}$ & $\begin{array}{l}\text { - Integration of indigenous } \\
\text { knowledge and traditional } \\
\text { practices while designing } \\
\text { climate action plan } \\
\text { - At policy level, financial } \\
\text { inclusion and land right to } \\
\text { women should be promoted }\end{array}$ \\
\hline 17 & Venot et al. (2010) & South India & $\begin{array}{l}\text { - Farmers are changing the } \\
\text { cropping patterns followed } \\
\text { by a drought and back to } \\
\text { normal crops in other years, } \\
\text { i.e. mostly adopting } \\
\text { short-term coping strategies }\end{array}$ \\
\hline 18 & Mishra and Mishra (2010) & Odisha & $\begin{array}{l}\text {-Adaptation options are } \\
\text { undertaken based on the } \\
\text { drought intensity }\end{array}$ \\
\hline 19 & Mwinjaka et al. (2010) & Gujarat & $\begin{array}{l}\text { - Additional government } \\
\text { interventions to assist poor } \\
\text { farmers are essential } \\
\text { - Greater coordination } \\
\text { between research, } \\
\text { monitoring and } \\
\text { technological institutes are } \\
\text { required } \\
\text { - Though several policies are } \\
\text { in place to withstand } \\
\text { drought, these are not } \\
\text { benefiting poor farmers } \\
\text { (e.g. food for work } \\
\text { programme, credit, } \\
\text { insurance, etc.) }\end{array}$ \\
\hline
\end{tabular}


(continued)

\begin{tabular}{|c|c|c|c|}
\hline S. No. & Author (Yyear) & Study location & Major findings \\
\hline 20 & Panda (2016) & Odisha & $\begin{array}{l}\text { - Major barriers: } \\
\text { - Household level: shortage of } \\
\text { water and irrigation facility, } \\
\text { knowledge about several } \\
\text { adaptation options and early } \\
\text { warning system } \\
\text { - Community level: lack of } \\
\text { government intervention, no } \\
\text { knowledge about drought } \\
\text { resistant crops and pro-active } \\
\text { renovation of water bodies } \\
\text { and irrigation systems }\end{array}$ \\
\hline \multirow[t]{2}{*}{21} & Udmale et al. (2014) & Maharashtra & $\begin{array}{l}\text { Farmers perceive climate } \\
\text { change, however, not adopt } \\
\text { sufficient options } \\
\text { - Low satisfaction for } \\
\text { government supported } \\
\text { drought mitigation } \\
\text { measures }\end{array}$ \\
\hline & \multicolumn{3}{|c|}{ Other hazards (Cyclonic Storms and Floods) } \\
\hline 22 & Duncan et al. (2017) & Odisha & $\begin{array}{l}\text { Factors related to social, } \\
\text { economic, institutional and } \\
\text { environmental are affecting } \\
\text { farmers' resilience capacity }\end{array}$ \\
\hline
\end{tabular}

Source Author's compilation from different studies

\section{References}

Ahmed, A. (2022). Autonomous adaptation to flooding by farmers in Pakistan. In A. K. E. Haque, P. Mukhopadhyay, M. Nepal \& M. R. Shammin (Eds.), Climate change and community resilience: Insights from South Asia (pp. 101-112). Springer Nature.

Aryal, J. P., Sapkota, T. B., Khurana, R., et al. (2019). Climate change and agriculture in South Asia: Adaptation options in smallholder production systems. Environment, Development and Sustainability, 22, 5045-5075.

Bahinipati, C. S. (2015). Determinants of farm-level adaptation diversity to cyclone and flood: Insights from a farm household-level survey in Eastern India. Water Policy, 17, 742-761.

Bahinipati, C. S., \& Venkatachalam, L. (2015). What drives farmers to adopt farm-level adaptation practices to climate extremes: Empirical evidence from Odisha, India. International Journal of Disaster Risk Reduction, 14(4), 347-356.

Balaji, V., Ganapuram, S., \& Devakumar, C. (2015). Communication and capacity building to advance adaptation strategies in agriculture in the context of climate change in India. Decision, 42(2), 147-158.

Banerjee, R. (2015). Farmer's perception of climate change, impact and adaptation strategies: A case study of four villages in the semi-arid regions of India. Natural Hazards, 75, 2829-2845. 
Banerjee, R., Kamanda, J., Bantilan, C., et al. (2013). Exploring the relationship between local institutions in SAT India and adaptation to climate variability. Natural Hazards, 65, 1443-1464.

Below, T., Artner, A., Siebert, R., \& Sieber, S. (2010). Micro-level practices to adapt to climate change for African small-scale farmers: A review of selected literature. IFPRI Discussion Paper 00953.

Bhatta, G. D., Aggarwal, P. K., Shrivastava, A. K., et al. (2016a). Is rainfall gradient a factor of livelihood diversification? Empirical evidence from around climatic hotspots in Indo-Gangetic Plains. Environment, Development and Sustainability, 18(6), 1657-1678.

Bhatta, G. D., Aggarwal, P. K., Kristjanson, P., et al. (2016b). Climatic and non-climatic factors influencing changing agricultural practices across different rainfall regimes in South Asia. Current Science, 110(7), 1272-1281.

Bird, F. A., Pradhan, A., Bhavani, R. V., \& Dangour, A. D. (2019). Interventions in agriculture for nutrition outcomes: A systematic review focused on South Asia. Food Policy, 82, 39-49.

Cariappa, A. G. A., Mahida, D. P., Lal, P., \& Chandel, B. S. (2020). Correlates and impact of crop insurance in India: Evidence from a nationally representative survey. Agricultural Finance Review. https://doi.org/10.1108/AFR-03-2020-0034

Dang, H. L., et al. (2019). Factors influencing the adaptation of farmers in response to climate change: A review. Climate and Development. https://doi.org/10.1080/17565529.2018.1562866

Devi, P. I., Sam, A. S., \& Sathyan, A. R. (2022). Resilience to climate stresses in South India: Conservation responses and exploitative reactions. In A. K. E. Haque, P. Mukhopadhyay, M. Nepal, \& M. R. Shammin (Eds.), Climate change and Community resilience: Insights from South Asia (pp. 113-127). Springer Nature.

Duncan, J. M., Tompkins, E. L., Dash, J., et al. (2017). Resilience to hazards: Rice farmers in the Mahanadi Delta India. Ecology and Society, 22(4), 3. https://doi.org/10.5751/ES-09559-220403

Ghosh, S., \& Roy, S. (2022). Climate change, ecological stress and livelihood choices in Indian Sundarban. In A. K. E. Haque, P. Mukhopadhyay, M. Nepal, \& M. R. Shammin (Eds.), Climate change and community resilience: Insights from South Asia (pp. 399-413). Springer Nature

Jain, M., Naeem, S., Orlove, B., et al. (2015). Understanding the causes and consequences of differential decision-making in adaptation research: Adapting to a delayed monsoon onset in Gujarat, India. Global Environmental Change, 31, 98-109.

Kakumanu, K. R., Kuppanan, P., Shalander, K., et al. (2016). Assessment of risk premium in farm technology adoption as a climate change adaptation strategy in the dryland systems of India. International Journal of Climate Change Strategies and Management, 8(5), 689-717.

Kharumnuid, P., Rao, I., Sudharani, V., et al. (2018). Farm level adaptation practices of potato growing farmers in East Khasi Hills district of Meghalaya India. Journal of Environmental Biology, 39(5), 575-580.

Khatri-Chhetri, A., Aggarwal, P., Joshi, P. et al., (2017). Farmer's prioritization of climate-smart agriculture (CSA) technologies. Agricultural Systems, 151, 184-191

Kumar, D. S., et al. (2011). An analysis of farmer's perception and awareness towards crop insurance as a tool for risk management in Tamil Nadu. Agricultural Economics Research Review, 24, 37-46.

Lobo, C., Chattopadhyay, N., \& Rao, K. V. (2017). Making smallholder farming climate-smart: Integrated agrometeorological services. Economic and Political Weekly, 52(1), 53-58.

Mehar, M., Mittal, S., \& Prasad, N. (2016). Farmers coping strategies for climate shock: Is it differentiated by gender? Journal of Rural Studies, 44, 123-131.

Mishra, S. K., \& Mishra, N. (2010). Vulnerability and adaptation analysis in flood affected areas of Orissa. Social Change, 40(2), 175-193.

Mishra, A., et al. (2013). Short-term rainfall forecasts as a soft adaptation to climate change in irrigation management in North-East India. Agricultural Water Management, 127, 97-106.

Morduch, J. (1995). Income smoothing and consumption smoothing. Journal of Economic Perspectives, 9(3), 103-114.

Mwinjaka, O., Gupta, J., \& Bresser, T. (2010). Adaptation strategies of the poorest farmers in drought-prone Gujarat. Climate and Development, 2(4), 346-363. 
Panda, A. (2013). Climate variability and the role of access to crop insurance as a social-protection measure: Insights from India. Development Policy Review, 31(2), 57-73.

Panda, A. (2016). Exploring climate change perceptions, rainfall trends and perceived barriers to adaptation in a drought affected region in India. Natural Hazards, 84(2), 777-796.

Panda, A., et al. (2013). Adaptive capacity contributing to improved agricultural productivity at the household level: Empirical findings highlighting the importance of crop insurance. Global Environmental Change, 23, 782-790.

Pandey, R., et al. (2018). Climate change adaptation in the Western-Himalayas: Household level perspectives on impacts and barriers. Ecological Indicators, 84, 27-37.

Patil, V. S., et al. (2018). Adapting or changing water? Crop choice and farmer's responses to water stress in peri-urban Bangalore, India. Irrigation and Drainage, 68, 140-151.

Patnaik, U., Das, P. K., \& Bahinipati, C. S. (2019). Development interventions, adaptation decisions and farmer's well-being: Evidence from drought prone households in rural India. Climate and Development, 11(4), 302-318.

Pielke, R. J., et al. (2007). Lifting the taboo on adaptation. Nature, 455(8), 597-598.

Pingali, P., et al. (2019). Transforming food systems for a rising India. Palgrave Macmillan.

Rao, C. S. R., et al. (2017). Farm-pond for climate resilient rain-fed agriculture. Current Science, 112(3), 471-477.

Rengalakshmi, R., Manjula, M., \& Devaraj, M. (2018). Making climate information communication gender sensitive: Lessons from Tamil Nadu. Economic and Political Weekly, 53(17), 87-95.

Sahu, N. C., \& Mishra, D. (2013). Analysis of perception and adaptability strategies of the farmers to climate change in Odisha, India. APCBEE Procedia, 5, 123-127.

Shaffril, H. A. M., Krauss, S. E., \& Samsuddin, S. F. (2018). A systematic review on Asian farmer's adaptation practices towards climate change. Science of the Total Environment, 644, 683-695.

Sharma, U., \& Patwardhan, A. (2008). An empirical approach to assessing generic adaptive capacity to tropical cyclone risk in coastal districts of India. Mitigation and Adaptation Strategies for Global Change, 13(8), 819-831.

Singh, C., Dorwarda, P., \& Osbahra, H. (2016). Developing a holistic approach to the analysis of farmer decision-making: Implications for adaptation policy and practice in developing countries. Land Use Policy, 59, 329-343.

Singh, R. K., et al. (2017). Perceptions of climate variability and livelihood adaptations relating to gender and wealth among the Adi community of the Eastern Indian Himalayas. Applied Geography, 85, 41-52.

Singh, C., et al. (2018a). Risks and responses in rural India: Implications for local climate change adaptation action. Climate Risk Management, 21, 52-68.

Singh, N. P., Anand, B., \& Khan, M. A. (2018b). Micro-level perception to climate change and adaptation issues: A prelude to mainstreaming climate adaptation into developmental landscape in India. Natural Hazards, 92, 1287-1304.

Singh, C., et al. (2020). Assessing the feasibility of adaptation options: Methodological advancements and directions for climate adaptation research and practice. Climatic Change, 162, 255-277.

Tripathi, A., \& Mishra, A. K. (2017a). Farmers need more help to adapt to climate change. Economic and Political Weekly, 52(24), 53-59.

Tripathi, A., \& Mishra, A. K. (2017b). Knowledge and passive adaptation to climate change: An example from Indian farmers. Climate Risk Management, 16, 195-207.

Udmale, P., et al. (2014). Farmer's perception of drought impacts, local adaptation and administrative mitigation measures in Maharashtra state, India. International Journal of Disaster Risk Reduction, $10,250-269$.

Venot, J. P., et al. (2010). Farmer's adaptation and regional land-use changes in irrigation systems under fluctuating water supply, south India. Journal of Irrigation and Drainage Engineering, 136(9), 595-609.

Vidanage, S. P., Kotagama, H. B., \& Dunusinghe, P. M. (2022). Sri Lanka's small tank cascade systems: Building agricultural resilience in the dry zone. In A. K. E. Haque, P. Mukhopadhyay, 
M. Nepal, \& M. R. Shammin (Eds.), Climate change and community resilience: Insights from South Asia (pp. 225-235). Springer Nature.

Wisner, B., et al. (2003). At risk: Natural hazards, people's vulnerability and disasters (2nd ed.). Routledge.

Open Access This chapter is licensed under the terms of the Creative Commons AttributionNonCommercial-NoDerivatives 4.0 International License (http://creativecommons.org/licenses/bync-nd/4.0/), which permits any noncommercial use, sharing, distribution and reproduction in any medium or format, as long as you give appropriate credit to the original author(s) and the source, provide a link to the Creative Commons licence and indicate if you modified the licensed material. You do not have permission under this licence to share adapted material derived from this chapter or parts of it.

The images or other third party material in this chapter are included in the chapter's Creative Commons licence, unless indicated otherwise in a credit line to the material. If material is not included in the chapter's Creative Commons licence and your intended use is not permitted by statutory regulation or exceeds the permitted use, you will need to obtain permission directly from the copyright holder.

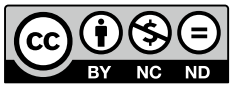

